\title{
Analisis Unsur Serapan Pada Media Luar Ruangan Di Kecamatan Padangsidimpuan Utara
}

\author{
Fauziah Nasution ${ }^{1}$,Elissa Evawani Tambunan ${ }^{2}$,Tinur Rahmawati Harahap ${ }^{3}$ \\ 1,2,3 Universitas Graha Nusantara Padangsidimpuan \\ Email: fauziahnasution05@gmail.com ${ }^{1}$ \\ elissaevawanitambunan04@gmail.com² \\ tinurrahmawati@gmail.com $^{3}$
}

\begin{abstract}
Abstrak
Penelitian ini bertujuan untuk mengetahui gambaran unsur serapan pada media luar ruangan di Kecamatan Padangsidimpuan Utara. Penelitian ini merupakan penelitian kualitatif dan sumber data dalam penelitian ini diambil dari spanduk dan papan nama yang ada di Kota Padangsidimpuan.Dari hasil penelitian yang telah dilakukan dengan menggunakan 3 (tiga) indikator diperoleh hasilnya yaitu; (1). Papan nama dan spanduk yang menggunakan bahasa asing ditemukan sebanyak 18 buah papan nama dan 15 buah spanduk (2). Papan nama dan spanduk yang penulisannya tidak memperhatikan EYD ditemukan 10 buah papan nama dan 12 buah spanduk. (3). Papan nama dan spanduk yang secara keseluruhan menggunakan bahasa Indonesia ditemukan 5 buah spanduk dan 5 buah papan nama. Kesimpulan yang diperoleh adalah terdapat kesalahan penulisan unsur serapan yang ada pada media luar ruang (papan nama dan spanduk) di Kota Padangsidimpuan. Yaitu: Papan nama 11 dan Spanduk 7 jumlah keseluruhan papan nama dan spanduk 32. Berdasarkan hasil penelitian, kesalahan keseluruhan penulisan unsur serapan pada media luar ruang (papan nama dan spanduk) di Kota Padangsidimpuan mencapai 18 hal ini menunjukan bahwa penulisan unsur serapan pada media luar ruang tidak mencapai kesempurnaan dikarenakan dalam penulisannya sering dijumpai kata-kata ejaannya yang kurang tepat dalam penulisannya, terdapat kesalahan struktur penulisan,pemakaian huruf-huruf, penulisan huruf, dan tanda baca. Sedangkan penulisan papan nama dan spanduk yang tidak memperhatikan EYD. Total keseluruhan kesalahan papan nama dan spanduk yang tidak memperhtaikan EYD. Jumlah keseluruhan papan nama dan spanduk 32 buah. Papan nama yang tidak sesuai dengan EYD sebanyak 12 dan spanduk yang tidak sesuai dengan EYD 8 buah. Jadi total kesalahan papan nama dan spanduk yang tidak memperhatikan EYD sebanyak 20 buah.
\end{abstract}

\section{Kata Kunci : Analisis, Unsur Serapan, Media Luar Ruangan}

\section{PENDAHULUAN}

Semua aktifitas manusia dalam kehidupan sehari-hari tidak dapat dipisahkan dari kegiatan berbahasa. Bahasa merupakan alat komunikasi antar individu yang satu dengan yang lainnya, baik lisan maupun tulisan. Wibowo (2009) mengemukakan "Pengertian komunikasi yang dimaksud adalah memahami dan mengungkapkan informasi, pikiran, perasaan serta mengembangkan ilmu pengetahuan, teknologi, dan budaya dengan menggunakan bahasa Indonesia".

Bahasa adalah alat komunikasi, tanpa bahasa seorang tidak bisa berkomunikasi, untuk itu seseorang perlu memiliki suatu keterampilan berbahasa. Bahasa Indonesia dalam perkembangannya diharapkan mampu berkembang menjadi bahasa yang lebih mantap dan dinamis sebagai bahasa internasional, untuk mencapai harapan itu, maka peranan ilmu pengetahuan dan teknologi merupakan faktor utama dalam perkembangan bahasa Indonesia. Misal, majunya telekomunikasi massa (televisi, radio, papan nama, reklame, spanduk) sebagai media alternatif perkembanngan bahasa.

Berkaitan dengan defenisi yang ada, bahwa papan nama, spanduk, reklame merupakan media untuk memberi petunjuk kepada masyarakat dengan menggunakan bahasa. Berkaitan dengan judul yang penulis teliti, ciri bahasa yang khas dimiliki dalam penulisan papan nama tak jauh beda dengan ciri penulisan lainnya seperti, spanduk dan sebagainya. Papan nama juga merupakan serangkaian kalimat 
informasi yang ditujukan kepada khalayak ramai tanpa mengenal batas status, usia dan golongan.

"Pembelajaran bahasa Indonesia secara fungsional dan komunikatif adalah pembelajaran yang lebih menekankan untuk belajar berbahasa, dalam kaitannya dengan fungsi sebagai alat komunikasi. Orang bukan sekedar belajar tentang pengetahuan bahasa, melainkan belajar menggunakan bahasa untuk keperluan berkomunikasi, baik lisan maupun tulisan”( http.www.google.media luar ruang).

Salah satu aspek keterampilan berbahasa yang berkaitan dengan pengungkapan pikiran, gagasan, pendapat, dan perasaan melalui media luar ruang adalah penggunaan keterampilan menulis unsur serapan yang harus sesuai dengan aturan atau kaedah penggunaan bahasa yang baik dan benar. Media luar ruang atau papan nama dan spanduk pada dasarnya merupakan sarana penyampaian pesan kepada pembaca yang bertujuan untuk memperkenalkan atau memberikan informasi bahasa dalam media luar ruang.

Penggunaan media luar ruang khususnya papan nama seringkali tidak memperdulikan aspek atau kaedah penggunaan unsur serapan yang baik, yang sesuai dengan pedoman ejaan yang disempurnakan bahasa Indonesia. Hal ini terbukti dengan banyaknya dijumpai kesalahan pemakaian unsur serapan pada penulisan papan nama dan spanduk di Kota Padangsidimpuan khususnya di kawasan Jalan Sutan Soripada Mulia kelurahan sadabuan seperti: papan nama dan spanduk yang pernah peneliti lihat misalnya penulisan kata, singkatan, penulisan bahasa asing, dan penulisan unsur serapan. Contoh: Poto copy Mutiara, Apotik Sadabuan dan lainnya.

Kesalahan-kesalahan dalam penulisan pada papan nama dan spanduk banyak terjadi pada pemakaian unsur serapan yang menggunakan bahasa asing, ditulis menggunakan bahasa campuran, masalah ini jika tidak diperbaiki, maka akan memberikan dampak negatip pada masyarakat, karena mereka akan berfikir penulisan pada media luar ruang tersebut di anggap penulisannya sudah benar. Bahan pertimbangan atau alasan peneliti ambil yaitu:

1. Penulisan unsur serapan harus benar-benar diperhatikan, karena tidak semua mengunakan bahasa baku.

2. Penulisan unsur serapan dalam iklan yang di maksudkan dapat mewakili makna kata menjadi lebih jelas dan singkat.

Penggunaan papan nama dan spanduk sebagai alat penyampaian pesan pada dasarnya sangat efektif untuk mendorong masyarakat luas mengetahui lebih tahu informasi yang ingin disampaikan. Sesuai dengan uraian pada latar belakang di atas, maka penulis tertarik untuk meneliti tentang unsur serapan dalam media luar ruang di Kota Padangsidimpuan, yang akan di sajikan dalam skripsi ini yang di beri judul "Analisis Penulisan Unsur Serapan Pada Media Luar Ruang (Papan Nama dan Spanduk) di Kota Padangsidimpuan"

\section{Hakikat Unsur Serapan}

Unsur serapan merupakan penulisan yang di dalamnya tercampur bahasa asing ataupun bahasa daerah. Unsur serapan sering dipergunakan dalam media cetak maupun dalam kehidupan sehari-hari. Dalam hal media cetak unsur serapan dipergunakan untuk menarik para pelanggan maupun khalayak ramai.

Muliono (2009) berpendapat dalam konteks kebahasaan yang dimaksud dengan "unsur serapan adalah unsur yang berasal dari bahasa asing atau bahasa daerah. Baik berupa imbuhan, kosakata, maupun peristilahan, yang dipungut atau diserap ke dalam bahasa Indonesia. Dalam hal ini unsur serapan itu dengan sendirinya kemudian menjadi "warga" bahasa Indonesia oleh karena itu, unsur serapan tersebut dapat diperlakukan seperti halnya unsurunsur dalam bahasa Indonesia".

Penyerapan unsur-unsur dari bahasa lain, baik dari bahasa daerah, bahasa serumpun, maupun bahasa-bahasa asing sebenarnya sudah lama dilakukan dalam bahasa Indonesia. Penyerapan itu dimaksudkan untuk menunjang perkembangan bahasa Indonesia agar bahasa kita itu dapat menjadi bahasa-bahasa yang moderen dan sanggup mengembangkan fungsi-fungsinya sebagai sarana kumunikasi dalam berbagai segi kehidupan dewasa ini.

Chaer (2004) berpendapat"'Kata serapan adalah kata-kata yang berasal dari bahasa asing atau bahasa daerah, lalu digunakan dalam bahasa 
Indonesia”. Tama berpendapat (2010) berdasarkan taraf integrasinya unsur serapan dalam bahasa Indonesia dapat dibagi atas tiga golongan besar yaitu:

1. Unsur-unsur yang sudah lama terserap ke dalam bahasa Indonesia yang tidak perlu lagi diubah ejaannya. Misalnya, sirsak, iklan, otonomi, dongkrak, pikir, paha.

2. Unsur asing yang belum sepenuhnya terserap ke dalam bahasa Indonesia. Pengucapannya masih mengikuti cara asing seperti shuttle. cock, restate.

3. Unsur pengucapannya dan penulisannya disesuikan dengan kaidah bahasa Indonesia. Ejaan di ubah hanya seperlunya saja sehingga bentuk Indonesianya masih dapat dibandingkan dengan bentuk bahasa aslinya.

Selanjutnya Wibowo (2001:3) berpendapat bahwa Bahasa Indonesia ialah merupakan bahasa yang hidup, yang terus menghasilkan kata-kata baru, baik melalui penyerapan dari bahasa daerah dan bahasa asing. Karena itu, tidak mungkin kita berbicara tentang bahasa Indonesia menyinggung bahasa daerah dan bahasa asing". Ketiganya merupakan suatu yang padu, tidak dapat dipisah-pisahkan, dan memiliki hubungan timbal-balik. Hubungan ini mempunyai dampak positif maupun negatif. Dengan terang dan jelas Pusat Pembinaan dan Pengembangan bahasa telah membuat tiga peraturan cara penyerapan istilah asing ke dalam bahasa Indonesia yaitu: penerjemahan, penyerapan, penyerapan dan penerjemahan sekaligus.

Tidak seluruh papan nama, reklame, spanduk ditulis dengan menggunakan bahasa Indonesia, ada juga beberapa papan nama dan spanduk yang ada di Kota Padangsidimpuan ditulis dengan menggunakan bahasa asing. Lisda (2008:6) beberapa alasan dipakai bahasa asing dalam membuat papan nama dan spanduk tersebut diantaranya:

1. Mengingat eksistensi dari bahsa asing itu sendiri dalam masyarakat khususnya bahasa Inggris, maksudnya dengan mengunakan bahasa Inggris dalam penulisan itu diharapkan dapat menciptakan daya tarik sendiri bagi masyarakat, sehingga masyarakat menganggap hal tersebut merupakan suatu yang mutakhir.

2. Pada zaman sekarang persaingan tidak lagi bersifat lokal yang hanya mengandalkan pengunaan bahasa Indonesia saja melainkan menggunakan bahasa asing yang dipandanng lebih efektif dalam kompetisi tersebut

3. Gengsi status sosial yang lebih tinggi yang dikandung oleh bahasa asing dibandingkan bahasa Indonesia.

Senada dengan pendapat di atas, Khasali (2005) mengemukakan Industri ini telah tumbuh secara pesat dan menjadi industri padat karya yang mengabungkan teknologi tinggi dari berbagai bidang untuk kepentingan dunia periklanan. Hampir dapat dipastikan bahwa dalam bidang ini pihak pengiklan akan lebih efisien menggunakan jasa perusahaan media luar ruang daripada mengurus dan memasangnya sendiri.

Berdasarkan uraian beberapa pendapat yang dikemukakan di atas dapat disimpulkan unsur serapan adalah penggunaan kata dalam kalimat tertentu yang menggunakan beberapa bahasa asing atau bahasa daerah di dalamnya yang bertujuan untuk menarik minat khalayak ramai terhadap tujuan yang disampaikan.

\section{Unsur Serapan Yang diserap dalam Bahasa Indonesia}

Dalam perkembangannnya, bahasa Indonesia menyerap unsur dari berbagai bahasa lain, baik dari bahasa daerah maupun dari bahasa asing seperti sangsakerta, Arab, Portugis, Belanda, atau Inggris. Depdikbud (2001:76) berdasarkan taraf Integrasinya unsur pinjaman dalam bahasa Indonesia dapat dibagi atas tiga golongan yaitu:

1. Unsur pinjaman yang belum sepenuhnya terserap kedalam bahasa Indonesia, seperti, shuttle cock, real estate. Unsur-unsur ini dapat dipakai dalam konteks bahasa Indonesia, tetapi pengucapnnya masih mengikuti cara asing.

2. Unsur pinjaman yang pengucapannya dan penulisannya disesuikan dengan kaidah 
bahasa Indonesia. Dalam hal ini diusahakan agar ejaannya hanya diubah seperlunya sehinngga bentuk indonesianya masih bisa dibandingkan dengan bentuk aslinya.

3. Unsur asing yang belum sepenuhnya terserap ke dalam bahasa Indonesai yang tidak perlu lagi diubah ejaannya. Misalnya, sirsak, iklan, otonomi, dongkrak, pikir, paha, aki.

Penulisan ejaan asing dalam ejaan bahasa Indonesia harus memperhatikan kaidah bahasa Indonesia yang berlaku. Begitu juga dalam penulisan ejaan unsur serapan kaidah yang berlaku juga harus diperhatikan. Sesui dengan penulisan ejaan unsur serapan dalam buku Pedoman Umum Ejaan Yang di Sempurnakan( EYD). Dalam penulisan unsur serapan, Ejaan Bahasa Indonesia yang telah disempurnakan merupakan pedoman utama bagi masyarakat yang menyadari betapa pentingnya menggunakan bahasa Indonesia yang baik dan benar. Kaidah penyesuaian ejaan bagi unsur serapan dilakukan dengan kaidah yang sesui dengan pedoaman EYD. Tama (2010:25) mengemukakan dalam penelitian kaidah ejaan penulisan kata unsur serapan, adalah sebagai berikut:

$$
\begin{array}{cr}
\text { 1) -aa ( Belanda ) menjadi a } \\
\text { baal } & \text { bal } \\
\text { paal } & \text { pal }
\end{array}
$$

- ae jika tidak bervariasi dengan e, tetap ae

aerobe aerob
aerosol aerosol

- c d muka a, o, u, dan konsonan menjadi $\mathrm{k}$

$\begin{array}{ll}\text { Calomel } & \text { kalomel } \\ \text { Vocal } & \text { vocal }\end{array}$

- c di muka e, I, oe, dan y menjadi s central sentral circulation sirkilasi

2) c (sanskerta) menjadai $s$ Cabda sabda Castra satra

- e tetap e

Effect efek

Synthesis sintesis

3) -ee (Belanda) menjadi e Stratosfeer stratosfer

\begin{tabular}{cc}
\multicolumn{1}{c}{ Systeem } & system \\
- e I tetap ei & \\
Eicosane & eikosan \\
Geometry & geometri \\
Zeolite & zeolit \\
- f tetap f & \\
Fanatic & fanatic \\
Factor & factor \\
Fossil & fosil \\
- gh menjadi g & \\
Sorghum & sorgum \\
4)-ie ( belanda) & menjadi I jika \\
lafalnya i & \\
politiek & politik \\
riem & rim
\end{tabular}

5)- kh (arab) menjadi kh Khusus

khusus

Akhir akhir

- ng tetap ng

Contingent contingent

Congres kongres

Linguistics linguistic

6)-oe ( oi yunani) menjadi e

Oestrogen estrogen

Oenology enologi

Foetus fetus

7)- oo ( Belanda) menjadi o

Komfoor kompor

Provost provos

8)- oo ( Inggris) menjadi $u$

$\begin{array}{ll}\text { Cartoon } & \text { kartun } \\ \text { Proof } & \text { pruf } \\ \text { Pool } & \text { pul } \\ \text { o (vocal ganda) } & \text { tetap } \\ \text { Zoology } & \text { zoology } \\ \text { Coordination } & \text { koordinasi }\end{array}$

Unsur serapan yang lazim dieja secara Indonesia tidak perlu lagi diubah, misalnya: kabar, iklan, bengkel, sirsak perlu, hadir. Sekalipun dalam ejaan yang disempurnakan huruf $\mathrm{q}$ dan $\mathrm{x}$ diterima sebagai bagian abjad bahasa Indonesia, unsur yang mengandung kedua huruf itu diindonesiakan menurut kaidah yang terurai di atas. Kedua huruf itu dipertahankan dalam pengunaan tertentu saja seperti dalam pembedaan nama dan istilah khusus. Jadi dapat disimpulkan kaidah ejaan unsur serapan yaitu, untuk melihat atau mengelompokan unsur pinjaman bahasa 
Indonesia diataskan teori ini.

\section{METODOLOGI}

Metode yang digunakan dalam penelitian ini adalah metode deskriptif kualitatif. Dalam metode deskriptif, data dikumpulkan dalam bentuk kata-kata atau gambar jika diperlukan, dan bukan berbentuk angka-angka. Hal ini disebabkan oleh adanya penerapan metode kualitatif. Selain itu, semua yang dikumpulkan berkemungkinan menjadi kunci terhadap apa yang sudah diteliti. Dan penelitian kulitatif yaitu penelitian dilakukan dengan tidak mengutamakan angka-angka, tetapi mengutamakan terhadap penghayatan terhadap interaksi antar konsep yang sedang dikaji (Bungin, 2003)

Data dalam penelitian ini dikategorikan sebagai data primer dan data sekunder. Data primer bersumber pada spanduk dan papan nama, dan data sekunder dari berbagai buku dan sumber lain yang berisi pembahasan para pakar sastra tentang berbagai hal yang berkenaan dengan unsur serapan yang dijadikan objek penelitian.

\section{HASIL DAN PEMBAHASAN}

\section{Papan Nama dan Spanduk yang Menggunakan Bahasa Asing}

Berdasarkan seluruh data yang diperoleh, papan nama dan spanduk tersebut menunjukan adanya variasi pembentukan nama yang didalamnya terdapat kedwibahasaan yaitu pencampuran antara bahasa Indonesia dengan bahasa asing. Setelah peneliti melakukan penelitian terhadap objek yang telah di lakukan maka diperoleh hasil tentang 2 hal yaitu:

\section{Papan nama}

Berdasarkan sampel yang penulis tetapkan maka unsur serapan pada pada papan nama peneliti hanya mengambi 18 buah dari keseluruhan pada papan nama yang ada di kecmatan Telanaipura.

\section{Spanduk}

Berdasarkan penelitian ini, kesalahan unsur serapan pada spanduk peneliti hanya mengambil 15 buah dari keseluruhan spanduk yang ada di Kota Padangsidimpuan.

\section{Papan Nama dan Spanduk yang Secara Keseluruhan Menggunakan Bahasa Indonesia}

Berdasarkan hasil penelitian yang dilakukan, penggunaan bahasa Indonesia dalam penulisan papan nama dan spanduk terdapat penyimpangan terhadap kaidah bahasa Indonesia dalam penulisan papan nama dan spanduk, dalam penulisan papan nama dan spanduk ini dibentuk atau disusun oleh unsurunsur bahasa Indonesia tetapi bentuk penulisanya masih mengandung unsur serapan.

Penulisan Pemakain Hurup yang Tidak Sesui dengan Kaidah EYD pada Papan Nama dan Spanduk

Penyimpangan terhadap kaidah bahasa Indonesia sering kita temui pada penulisan unsur serapan pada media luar ruang ( papan nama dan spanduk). Dalam penelitian ini ejaan yang diperhatikan penulisan huruf kapital dan penulisan kata. Untuk lebih jelasnya, kesalahan EYD dari kesalahan unsur serapan pada media luar ruang di Kota Padangsidimpuan dapat dilihat pada tabel berikut ini.

Tabel. 1. Gambaran Papan Nama di Kota Padangsidimpuan

\begin{tabular}{|c|c|c|}
\hline No & Penulisan yang Salah & Penulisan yang Benar \\
\hline 1 & $\begin{array}{l}\text { Padangsidimpuan Auto } \\
\text { Service }\end{array}$ & $\begin{array}{ll}\text { Servis } & \text { Mobil } \\
\text { Padangsdimpuan } & \end{array}$ \\
\hline 2 & Enha Supermarket & - \\
\hline 3 & $\begin{array}{l}\text { Raden } \text { Motor Sport } \\
\text { Centre }\end{array}$ & - \\
\hline 4 & $\begin{array}{ll}\text { Merdeka } & \text { Cipta } \\
\text { Elektrotronic } & \\
\end{array}$ & $\begin{array}{ll}\text { Merdeka } & \text { Cipta } \\
\text { Elektronik } & \\
\end{array}$ \\
\hline 5 & Yamaha Music School & Sekolah Musik Yamaha \\
\hline 6 & Thes Fashion & Busana Des \\
\hline 7 & Home Video & Rumah Video \\
\hline 8 & Executive Laundry & - \\
\hline 9 & You \& Me Beauty Home & - \\
\hline 10 & Hau's Tea & - \\
\hline 11 & Rapilo tailor & Penjahit Rapilo \\
\hline 12 & Anugrah Motor Service & Motor Servis Anugerah \\
\hline 13 & Saqila Shop & Toko Saqila \\
\hline 14 & Traffic Light Distro & - \\
\hline 15 & Kremezz Bang Gurfron & Kremess Bang Gurfron \\
\hline 16 & Apotik Merdeka & Apotek Merdeka \\
\hline 17 & Rilexindo Mobil Sentosa & - \\
\hline 18 & $\begin{array}{l}\text { Coffee } \text { Beringin Live } \\
\text { Music }\end{array}$ & $\begin{array}{lll}\text { Beringin coffee live } \\
\text { musik }\end{array}$ \\
\hline & Jumlah & 11 \\
\hline
\end{tabular}


Tabel. 2. Gambaran Spanduk di Kota Padangsidimpuan

\begin{tabular}{|c|l|l|}
\hline No & \multicolumn{1}{|l|}{ Penulisan yang Salah } & Penulisan yang Benar \\
\hline 1 & Fa'iz Motor & Motor fais \\
\hline 2 & Din-dong Tas \& Accessories & - \\
\hline 3 & Lusi Collection & Koleksi Lusi \\
\hline 4 & Fajar timur Fashion & Koleksi Busana Timur \\
\hline 5 & Zuge Net & - \\
\hline 6 & Kafe Nutrisi “Shake House” & - \\
\hline 7 & Rumah Makan Sugenng & - \\
\hline 8 & Kajol Collection & Koleksi Kajol \\
\hline 9 & Bakso Pa' Kumis & Bakso Pak kumis \\
\hline 10 & Foto Copy Alif & Fotokopi Alif \\
\hline 11 & Rudhi Advertising & - \\
\hline 12 & Falcon Wait Pain & - \\
\hline 13 & Nasi Uduk Bang Kulup & - \\
\hline 14 & $\begin{array}{l}\text { Suku Cadang Terpercaya } \\
\text { Toko Bintang }\end{array}$ & - \\
\hline 15 & Rahmat copy centre & Pusat fotokopi Rahmat \\
\hline & Jumlah & 7 \\
\hline
\end{tabular}

Berdasarkan penelitian yang dilakukan, maka kesalahan penulisan unsur serapan yang ada pada media luar ruang Papan nama 18 buah Spanduk 15 buah jumlah keseluruhan papan nama dan spanduk 32 buah. Kesalahan penulisan unsur serapan pada media luar ruang (papan nama dan spanduk) di Kota Padangsidimpuan.

Berdasarkan tabel di atas, dapat

spanduk yang tidak sesuai dengan EYD 8 buah. Jadi total kesalahan papan nama dan spanduk yang tidak memperhatikan EYD sebanyak 20 buah.

\section{KESIMPULAN}

Dari uraian di atas, maka dapat disimpulkan bahwa, kesalahan penulisan unsur serapan yang ada pada media luar ruang (papan nama dan spanduk) di Kota Padangsidimpuan. Yaitu: Papan nama 11 dan Spanduk 7 jumlah keseluruhan papan nama dan spanduk 32. Berdasarkan hasil penelitian, kesalahan keseluruhan penulisan unsur serapan pada media luar ruang (papan nama dan spanduk) di Kota Padangsidimpuan mencapai 18 hal ini menunjukan bahwa penulisan unsur serapan pada media luar ruang tidak mencapai kesempurnaan dikarenakan dalam penulisannya sering dijumpai kata-kata ejaannya yang kurang tepat dalam penulisannya, terdapat kesalahan struktur penulisan,pemakaian huruf-huruf, penulisan diketahui berapa banyak kesalahan unsur serapan pada media luar ruang (papan nama dan spanduk) di Kota Padangsidimpuan. Berdasarkan penelitian yang dilakukan, maka kesalahan penulisan unsur serapan yang ada pada media luar ruang (papan nama dan spanduk) di Kota Padangsidimpuan. Yaitu: Papan nama 11 dan Spanduk 7 jumlah keseluruhan papan nama dan spanduk 32 .

Berdasarkan hasil penelitian, kesalahan keseluruhan penulisan unsur serapan pada media luar ruang (papan nama dan spanduk) di Kota Padangsidimpuan mencapai 18 hal ini menunjukan bahwa penulisan unsur serapan pada media luar ruang tidak mencapai kesempurnaan dikarenakan dalam penulisannya sering dijumpai kata-kata ejaannya yang kurang tepat dalam penulisannya, terdapat kesalahan struktur penulisan,pemakaian huruf-huruf, penulisan huruf, dan tanda baca.

Sedangkan penulisan papan nama dan spanduk yang tidak memperhatikan EYD. Total keseluruhan kesalahan papan nama dan spanduk yang tidak memperhtaikan EYD. Jumlah keseluruhan papan nama dan spanduk 32 buah. Papan nama yang tidak sesuai dengan EYD sebanyak 12 dan

huruf, dan tanda baca.

Sedangkan penulisan papan nama dan spanduk yang tidak memperhatikan EYD. Total keseluruhan kesalahan papan nama dan spanduk yang tidak memperhtaikan EYD. Jumlah keseluruhan papan nama dan spanduk 32 buah. Papan nama yang tidak sesuai dengan EYD sebanyak 12 dan spanduk yang tidak sesuai dengan EYD 8 buah. Jadi total kesalahan papan nama dan spanduk yang tidak memperhatikan EYD sebanyak 20 buah.

Berdasarkan kesimpulan di atas, maka ada beberapa implikasi yang disampaikan sampaikan kepada pembaca. Pertama, diharapkan kepada pembaca lebih memperhatikan kaidah-kaidah penulisan yang baik dan benar menurut EYD. Kedua agar pembaca dapat mempergunakan hasil penelitian ini sebagai pedoman untuk membuat papan nama dan spanduk.

DAFTAR PUSTAKA

Alisjabana, S. Takdir. 2007. Dian Yang Tak 
Terakreditasi Peringkat 4 (No. SK: 36/E/KPT/2019)

Kunjung Padam. Jakarta : Dian Rakyat.

Profil Pengarang. (http://www. Sutan Takdir Alisjabana.net. Diakses 14 Desember 2009)

Bungin, Burhan. 2003. Teknik Analisis Kualitatif Dalam Penelitian Sosial. Jakarta.

Chamanah, Siti. 2001. Metodologi Penelitian Sastra edisi pertama. Yogyakarta.

Endraswara, Suwardi. 2008. Metodologi Penelitian Sastra edisi keempat. Yogyakarta.

Faruk.1994. Pengantar Sosiologi Sastra. Yogyakarta. 